upon the wire. Therefore there is no good reason to think that any thing would have been gained at that time by the use of heavy leads, though Mr. Dall thinks it strange that they were not tried. In some of the trials a twelve-pound lead was used, and, in the last attempt, one of eight pounds, together with a thermometer, with the usual result, - a breakage of the wire.

Mr. Dall's note implies that no successful trials were made with the steel wire; but, according to the published log ( $\mathrm{p} .93$, May 14; $1850)$, at least one sounding was made $(1,050$ fathoms, no bottom) when the wire was successfully recovered.

A. E. Verrill.

\section{LAKE BONNEVILLE.}

Mr. G. K. GilberT's report (Ann. rep. U. S. geol. surv., 1881, 169), preliminary to the monograph (in preparation) he promises on the Great Basin, shows the following history for its old lake. The lakedeposits are chiefly a yellow clay of unknown depth, covered by a white marl ten to twenty feet thick, the two being separated at certain points along the old shore-lines by wedges of subaerial gravel-deposits, and some exposures showing erosion of the clay surface before the marl was laid on it. These deposits mark two periods of high water, separated by a time of low water, or dryness. As no cause is found in the surrounding country to account for the change from clay to marl deposit, its explanation is sought in a change from salt water of the first lake period to fresh water in the second, for which a theoretic explanation is given; but the evidence for this is not considered final. From a critical study of the superposition of many shore terraces (see the plate opposite), it is shown that the first lake did not rise high enough to reach an overflow outlet; that the greater number of terraces now visible were formed during halts in the rise of the second great lake; that the highest or Bonneville terrace, nine hundred or more feet above the present Great Salt Lake, marks a stand at the level of overflow northward to Snake River; that the next most pronounced terrace, known as the Provo, four hundred feet lower, marks a halt in the drainage of the waters when the outlet had been cut down through softer rocks to a hard limestone sill. The reduction of the lake-surface to a still lower level, as in the present shallow sheet of water, has been effected entirely by climatic change, by which the ratio of precipitation to evaporation has been decreased. When at its highest level, Lake Bonneville was three hundred miles long between latitudes $37^{\circ} 40^{\prime}$ and $42^{\circ} 20^{\prime}$, and one hundred and seventy miles broad between the meridians $111^{\circ} 35^{\prime}$ and $114^{\circ} 15^{\prime}$ of west longitude. Its shore-line was very irregular, advancing around broken promontories, and retreating into fiord-like bays. Numerous islands stood above its broad, deep, fresh waters, and from its shores the enclosing mountains rose five to eight thousand feet. Now it is represented by a mere film of brine on the borders of a desert plain. Previous to the rise of the first lake, the base-level of the basin drainage was low for a long period, as is proved by the distinct overlap of the lacustrine rleposits on the eroded mountain-slopes, as shown in the second plate here copied on p. 573, or on the alluvial cones built by old streams flowing from the mountain valleys; but the conclusion that this long period had a dry climate is not fully proved. For if, as is mentioned below, a considerable tilting has already deformed the recently made Bonneville terrace, one may fairly suppose a much greater distortion in the long time since the beginning of the first lake; and this distortion may have been sufficient to raise a barrier behind which the lake-waters accumulated. The change from the prelacustrine condition would then have been orographic rather than climatic. The relation of the glaciation of the neighboring ranges to the lakes is not shown directly, althaugh three old moraines are found within the terrace limits; for none of these give good opportunity for observation, and the one at the mouth of Little Cottonwood cañon is so dislocated by recent faulting that its attitude with relation to the terraces cannot be deciphered. Recent discoveries by $\mathrm{Mr}$. I. C. Russell in the western part of the Great Basin may throw further light on this question. Volcanic eruption took place in the basin during the disappearance of Lake Bonneville; and both the Bonneville and Provo terraces have been warped from their originally level plains, and by different amounts. From measures taken along the eastern shore-lines, lines of equal deformation ale constructed; and these show very clearly a relative elevation of the centre, or south-western part, of the old lake-bottom of as much as three hundred feet since the Bonneville terrace was made, and a hundred and twenty-six since the Provo. This tilting accounts for the eccentric position of the present shallow lake-remnant at the north-eastern margin of its flat desert. A fault of fifty to seventy-five feet has been made along the foot of the Wahsatch range, between Willard and Levan, since the lake lost its outlet. The author therefore concludes that volcanic activity and mountain growth have not yet ceased in this neighborhood.

Special interest is attached to this investigation, as it is the first detailed study of an example of those great interior lakes so numerous at a comparatively recent period of the earth's history, and now so greatly reduced in area, or even converted into saline or sandy deserts. The largest of these was probably the one that united the Aral and the Caspian; another vast interior sea occupied much of what is now the desert of Gobi; and smaller examples could be named in the Argentine Republic and in northern Mexico. Central Africa, lying within the belt of heavy equatorial rains, still preserves a climate moist enough to fill its lakes to overflowing; but the recent drying-up of the outlet of Tanganyika shows that the change so distinct elsewhere is beginning to make itself felt even there. It will be long before any of these other great basins is known as well as that one so carefully studied by our government surveyors.

W. M. Davis.

\section{CHEMICAL AND PHYSIOLOGICAL RE- SEARCHES ON THE PTOMAÏNES.}

DURING the last few'years much attention has been directed to the study of the chemical nature and physiological action of the so-called post-mortem alkaloids (or ptomaïnes). These mysterious bodies, which are apparently formed in such small quantities as to make their detection and separation an extremely difficult operation, were originally regarded by both Selmi ${ }^{1}$ and Schwanert ${ }^{2}$ (1874) as exclusively

\footnotetext{
1 Abstract in Berichte deutsch. chem. gesellsch., vi. 142.
}

2 Berichte deutsch. chem. gesellsch, vii. 1332. 